\title{
Desain Interior Coffee Shop di Denpasar dan Loyalitas Konsumennya : Generasi Y dan Z
}

\author{
Ardina Susanti ${ }^{1}$ | Putu Surya Triana Dewi ${ }^{1}$ | I Wayan Yogik Adnyana Putra ${ }^{1}$ \\ ${ }^{1}$ Institut Desain dan Bisnis Bali, Denpasar \\ Corresponding author : Email: ardina@std-bali.ac.id
}

\begin{abstract}
ABSTRAK
Banyak brand coffee shop lokal turut hadir meramaikan pasar coffee shop di Bali, khususnya Kota Denpasar. Hal ini justru menghadirkan fenomena baru yang mempengaruhi desain interior dari coffee shop tidak lagi mementingkan luas ruang coffee shop, tetapi menghadirkan karakter desain interior yang lebih sederhana dengan tema yang unik. Variasi ini pun juga memiliki segmentasi konsumen tersendiri. Oleh karena itu, penelitian ini bertujuan menilai korelasi nilai sensualitas dari brand coffee shop dengan tingkat loyalitas konsumen terhadap brand coffee shop tersebut. Hal tersebut penting untuk diteliti lebih lanjut, karena dapat melihat secara detail peran dari desain interior terhadap suatu brand coffee shop dan juga terhadap pola konsumsi masyarakat. Penelitian ini menggunakan metode sequential mixedmethod menggunakan metode pendataan kuesioner untuk generasi Y dan Z, observasi dan wawancara langsung kepada konsumen dan pemilik coffee shop, dengan mengambil 5 studi kasus coffee shop yaitu Jenar Coffee, Simply Brew, Coffee Secret, Alleyway Coffee, dan Milestone Coffee. Hasil penelitian ini memperlihatkan bahwa elemen-elemen interior coffee shop yang memiliki pengaruh terhadap tingkat loyalitas konsumen adalah faktor fisik lingkungan seperti furnitur, pencahayaan, kombinasi warna, dekorasi interior, suara, temperatur, kualitas kopi yang baik berpengaruh pada aroma menyenangkan pada coffee shop, serta faktor non fisik lingkungan seperti interaksi sosial untuk meningkatkan kenyamanan seperti di rumah sendiri pada coffee shop. Peneliti berharap penelitian ini dapat memberikan kontribusi dalam proses perancangan desain interior untuk dapat melibatkan faktor-faktor yang meningkatkan loyalitas konsumen saat merancang interior sebuah coffee shop.
\end{abstract}

Kata Kunci: Desain interior, coffee shop, loyalitas, konsumen

\section{ABSTRACT}

Many local coffee shop brands are also present to enliven the coffee shop market in Bali, especially in Denpasar City. This actually presents a new phenomenon that affects the interior design of a coffee shop, that no longer emphasizes the area of the coffee shop space, but presents a simpler interior design character with a unique theme. This variation also has its own consumer segmentation. Therefore, this study aims to assess the correlation of the sensuality value of the coffee shop brand with the level of consumer loyalty to the coffee shop brand. This is important to research further, because it can see in detail about the role of interior design on a coffee shop brand and also on people's consumption patterns. This study uses a mixed-method sequential method using questionnaire data collection methods for generations $Y$ and $Z$, observation and direct interviews with consumers and coffee shop owners, wherein this research take 5 coffee shops as case studies, there are Jenar Coffee, Simply Brew, Coffee Secret, Alleyway Coffee, and Milestone Coffee. The results of this study indicate that the coffee shop interior elements that have impact to the level of consumer loyalty are physical environmental factors such as furniture, lighting, color combinations, interior decoration, sound, temperature, good coffee quality, which will affect the pleasant aroma of coffee shop, as well as non-physical environmental factors such as social interactions that can increase comfort, feels like home, at a coffee shop. Researcher hope the results of this studies can contribute in interior design process, to involves factors that can increase customers loyalty when design the coffee shop interior.

Keywords: Interior design, coffee shop, loyalty, consumer

\section{PENDAHULUAN}

Perkembangan teknologi yang semakin pesat mengakibatkan perubahan signifikan terhadap perilaku dan gaya hidup manusia. Revolusi industri 4.0 yang ditandai dengan perkembangan Internet of Things (IOT) sangat memberi perubahan signifikan bagi gaya hidup manusia khususnya dalam gaya konsumsi nilai dan barang, tidak hanya di Indonesia tapi gaya hidup manusia secara global. Salah satu contohnya adalah keberadaan media sosial yang sudah menjadi salah satu bagian dari kehidupan manusia pada era ini. 
Perkembangan teknologi hingga tahap ini tentu saja semakin memudahkan masyarakat untuk memilih gaya hidup yang ingin mereka jalankan. Dengan beragamnya gaya hidup yang dipilih oleh masyarakat, tentu akan mempengaruhi perancangan desain interior dari fungsi-fungsi yang mewadahi gaya hidup tersebut.

Salah satunya adalah keberadaan coffee shop yang semakin banyak bermunculan. Sebuah ruang atau bangunan yang berfungsi sebagai coffee shop merupakan sebuah tempat untuk menikmati minuman olahan dari kopi dengan makanan lain sebagai pendampingnya. Menurut Herlyana (2012), coffee shop merupakan sebuah tempat yang menyediakan berbagai jenis kopi dan minuman non alkohol lainnya yang dibalut dengan suasana santai, ruang yang nyaman, dilengkapi alunan musik, desain interior yang khas, fasilitas internet nirkabel, serta pelayanan yang ramah.

Fenomena menjamurnya coffee shop di Bali juga merupakan suatu fenomena baru, dengan banyak kegiatan bersosialisasi dan berkontemplasi juga dilakukan pada coffee shop. Dapat dikatakan bahwa budaya minum kopi memang sudah ada sejak zaman dahulu sebagai kegiatan sehari-hari, kini bertransformasi menjadi sebuah budaya baru yakni minum kopi pada sebuah coffee shop juga mencitrakan sebuah tren dan status sosial. Dengan demikian, hal ini merupakan tantangan bagi pengusaha coffee shop untuk mampu bersaing dan mengembangkan brand coffee shop miliknya dalam era industri 4.0., tidak hanya mengandalkan produk, tapi juga faktor-faktor lainnya seperti kualitas layanan, dan desain interior dari coffee shop tersebut. Perkembangan coffee shop di Bali memang diawali dari hadirnya coffee shop ternama seperti Starbucks Coffee, The Coffee Bean, Black Canyon Coffee, The Excelso, dan lain-lain. Seiring berjalannya waktu dengan melihat maraknya gaya hidup nongkrong di coffee shop, membuat banyak brand coffee shop lokal turut hadir meramaikan pasar ini. Hal ini justru menghadirkan fenomena baru yang mempengaruhi desain interior dari coffee shop itu sendiri, yaitu dari karakter coffee shop dari brand ternama yang identik dengan desain interior luas, kontemporer dan terkesan mewah, kini hadir variasi lainnya dari beberapa coffee shop lokal yang tidak lagi mementingkan luas ruang coffee shop, tapi menghadirkan karakter desain interior lebih sederhana dengan tema unik. Variasi ini pun juga memiliki segmentasi konsumen tersendiri.
Oleh karena itu, penelitian ini bertujuan menilai korelasi nilai sensualitas dari brand coffee shop dengan tingkat loyalitas konsumen terhadap brand coffee shop tersebut. Hal tersebut penting untuk diteliti lebih lanjut, karena dapat melihat secara detail peran dari desain interior terhadap suatu brand coffee shop dan juga terhadap pola konsumsi masyarakat. Dengan demikian, hal ini mampu menemukan peran lain dari sebuah ruang, tidak hanya sekadar wadah dari sebuah aktivitas, tapi juga berperan dalam transformasi perilaku konsumsi masyarakat yang juga memberikan andil dalam transformasi budaya.

Penelitian ini dikhususkan untuk melihat persepsi dari konsumen generasi $\mathrm{Y}$ dan $\mathrm{Z}$ karena generasi ini yang akan menjadi pemegang kegiatan ekonomi baik di Indonesia maupun secara global hingga 10 tahun ke depan, serta kasus coffe shop yang akan diangkat adalah coffee shop dengan brand lokal.

\section{Desain Interior, Brand, dan Loyalitas Konsumen}

Hubungan antara manusia dengan ruang adalah sebuah hubungan yang kompleks dengan manusia dapat menjelaskan ruang, sebaliknya ruang juga dapat menjelaskan manusia penggunanya. Manusia dapat memberi makna pada ruang dan ruang pun dapat memberi makna pada manusia penggunanya (Mahmoud, 2017). Berdasarkan hasil penelitian yang dilakukan oleh Mahmoud (2017), terdapat tujuh elemen dari desain arsitektural dan interior yang memberikan dampak bagi psikologi dan perilaku manusia, antara lain: elemen identitas, privasi, fungsional-fleksibilitas, keamanankesehatan, aksesibilitas-sirkulasi, ruang luar, dan estetika.

Dalam konteks sebuah bangunan dengan fungsi komersil seperti coffee shop, desain interior ternyata berpengaruh signifikan terhadap atmosfer ruang berdampak pada pengalaman yang dirasakan konsumen, baik itu pengalaman positif maupun negatif. Penelitian yang dilakukan oleh Pecoti et.al. (2014) telah mampu menjabarkan pengaruh elemen-elemen desain interior restaurant yang memiliki pengaruh positif terhadap kepuasan konsumen, sehingga meningkatkan loyalitas konsumen untuk datang kembali. Faktor-faktor yang berpengaruh adalah faktor pencahayaan/ ambient lighting dengan pencahayaan yang terlalu terang membuat konsumen tidak betah berlamalama pada tempat tersebut; faktor warna dengan kombinasi warna yang cenderung hangat (warm) lebih disukai oleh konsumen; faktor musik terkait juga dengan faktor kebisingan, dengan musik 
lembut bervolume tidak terlalu keras lebih disukai konsumen karena dapat memberikan suasana tenang; faktor tableware (peralatan makan) juga memiliki pengaruh terhadap kepuasan konsumen terutama dalam hal desain piring dan gelas; faktor luasan ruang, konsumen ternyata menyukai jarak antar meja yang sedang, tidak terlalu sesak dan tidak terlalu berjauhan; dan terakhir faktor kenyamanan furnitur juga menjadi pertimbangan terpenting dalam kepuasan konsumen terutama dalam hal material furnitur, hal ini senada dengan hasil penelitian Azzuhri et.al. (2017), dengan kenyamanan furnitur memiliki andil paling besar dalam keinginan konsumen untuk menghabiskan waktu di dalam kafe sehingga akan meningkatkan loyalitas.

Aspek loyalitas dalam proses konsumsi sangat dipengaruhi oleh keberadaan dan kekuatan dari brand. Sebuah brand dipandang sebagai elemen sentral dari paham kapitalisme konsumen (consumer capitalism). Dalam paham ini, brand memiliki fungsi utama yang tidak lagi berfungsi untuk melindungi produk asli dari produk imitasinya, tapi juga untuk menemukan dan menciptakan sebuah identitas dan gaya hidup baru. Dengan demikian, keberadaan dari brand menciptakan nilai ekonomi baru yaitu ekonomi dalam penanda (economy of sign), dengan produsen tidak lagi hanya fokus pada pembuatan produk tapi cenderung fokus kepada penciptaan simbol-simbol dari sebuah brand, yang dapat memberi nilai lebih pada aura brand tersebut kepada konsumen. Oleh karena itu, dalam ekonomi modern sebuah brand selain menawarkan produk, di saat yang bersamaan juga menawarkan gaya hidup dan identitas kepada pembelinya (Ermann, 2011). Hal ini juga terjadi pada fenomena coffee shop yang mengubah aktivitas minum kopi biasa menjadi sebuah citra dari identitas dan gaya hidup.

Menurut penelitian dari Song et.al (2019) menyatakan bahwa nilai sensualitas dari sebuah brand coffee shop berpengaruh signifikan terhadap tingkat kecintaan konsumen terhadap brand tersebut (brand love), dan loyalitas mereka untuk mengkonsumsi produk-produk dari brand tersebut (brand loyalty). Sensualitas dari sebuah brand adalah pengalaman-pengalaman sensual yang terbangun dari pengalaman sensasi kelima indera yang konsumen rasakan saat menggunakan atau mengkonsumsi produk dari brand, dengan musik, interior, warna, dan aroma merupakan contoh dari sensasi tersebut. Dalam penelitian ini, Peneliti mengukur nilai sensualitas brand dari pertanyaanpertanyaan yang terkait dengan keunikan sensasi- sensasi yang dihadirkan oleh coffee shop, atraktivitas dari desain interior, serta keindahan secara visual yang dihadirkan oleh coffee shop.

Loyalitas yang sangat tinggi berujung pada perilaku fetisisme komoditas yaitu suatu rangkaian dari sebuah proses konsumsi sebuah produk setelah perilaku konsumsi menjadi bersifat konsumtif lalu berkembang menjadi gaya hidup (Putlia, 2018). Dalam penelitian Putlia (2018) didapatkan hasil bahwa fetisisme komoditas diawali oleh motivasi hedonis yang terkait dengan pemenuhan kebutuhan secara material. Putlia $(2018$;2019) melakukan dua penelitian dengan metode yang sama dalam kasus yang berbeda. Pada penelitian pertama, dilakukan pengambilan data pada coffee shop dari brand internasional, dengan hasil terjadinya fetisisme komoditas terhadap brand tersebut. Kemudian pada penelitian kedua dilakukan pengambilan data pada coffee shop dari brand lokal, memberikan hasil bahwa responden berperilaku konsumtif tapi tidak terjebak dalam fetisisme komoditas. Hal ini menjadi menarik karena perbedaan kekuatan brand sangat mempengaruhi perilaku konsumsi dari konsumennya.

\section{Pemasaran Multi Sensorik, Brand Sensuality, dan Brand Experience}

Dalam sebuah disertasi yang ditulis oleh Clarinda Rodrigues (2014), yang berjudul 'Brand Sensuality and Consumer-Based Brand Equity', melakukan sebuah analisis mengenai awal mula terbentuknya brand sensuality, dengan mengaitkannya dengan Consumer-Based Brand Equity (CBBE). Terdapat empat konsep dalam CBBE yaitu brand personality, brand relationship, dan brand experience. Brand experience merupakan konsep yang sangat terkait dengan pengoptimalan indera dari manusia dalam menerjemahkan dan mengapresiasi sebuah nilai dari brand (brand value). Nilai brand terbentuk menggunakan perceived value dari konsumen saat proses konsumsi brand. Dengan demikian strategi sensorial melalui penglihatan, suara, pengecapan, pembauan dan sentuhan memegang peranan penting untuk menyampaikan nilai brand kepada konsumen.

Indera manusia dalam hal ini disadari sebagai media yang menghubungkan manusia dengan dunia yang ada di sekitar mereka. Terkait dengan barang dan jasa, indera manusia melalui pengalaman sensasi dan sensorik dipertimbangkan sebagai strategi dalam pemasaran, sehingga memunculkan strategi pemasaran multi sensorik. 
Pemasaran multi sensorik merupakan sebuah strategi pemasaran yang melibatkan indera-indera dari konsumen yang pada akhirnya akan mempengaruhi perilakunya. Hal ini didasarkan pada setiap individu memiliki pengalaman subyektif sebagai pengalaman logika. Logika tersebut bersifat sangat personal berdasarkan bagaimana indera menerima dan menginterpretasikan pengalaman brand tersebut secara multi sensorik (Rodrigues, 2014).

Beberapa penelitian sebelumnya terkait tentang indera penglihatan yang dilakukan oleh Hertenstein dan Platt, serta Wallace (dalam Rodrigues, 2014) menunjukkan tingkat korelasi yang tinggi antara kualitas desain dari stimulus visual terhadap performa finansial dari sebuah produk atau jasa sebuah brand. Stimulus visual tersebut menurut penelitian Hulten (2017) adalah iklan, warna, desain secara keseluruhan, pencahayaan, logo, kemasan, desain produk, dan stimulus visual lainnya yang memungkinkan untuk mendiferensiasi produk, meningkatkan loyalitas, mencegah kekacauan penglihatan dan mencegah persaingan dengan kompetitor. Indera penciuman dianggap paling kuat dalam hal menguatkan memori terhadap produk dalam penelitian yang dilakukan oleh Aggleton \& Wasket (dalam Rodrigues, 2014). Persepsi secara olfaktori bersifat hedonis dan sangat mempengaruhi gairah dari konsumen (Rodrigues, 2014) sehingga aroma memberikan pengaruh yang positif pada evaluasi mengenai toko dan produk yang ditawarkan. Berdasarkan hasil penelitian tersebut dapat disimpulkan bahwa aroma yang menyenangkan (pleasant scent) akan meningkatkan perilaku berbelanja, sehingga aroma (scents) dapat digunakan sebagai strategi marketing untuk mengekspresikan identitas brand dan menguatkan brand image. Aroma yang dianggap sebagai pleasant scents adalah aroma roti, kopi, dan parfum. Sedangkan aroma yang dianggap unpleasant scents adalah aroma keringat, makanan basi, dan sampah.

Indera perabaan akan menguatkan perbedaan dalam hal motivasi individu untuk menyentuh sebuah produk. Media-media yang mendukung persepsi dan evaluasi dari indera perabaan adalah material benda, permukaan benda, temperatur, berat, bentuk dan kekuatan dapat berkontribusi secara positif terhadap pengalaman sentuhan pada sebuah brand dan mampu membedakan satu brand dengan kompetitornya. Selain itu menurut Peck and Childers (dalam Rodrigues, 2014) perabaan dapat mengantarkan persepsi individu untuk mendapatkan informasi lebih dari produk yang dapat menguatkan afeksi positif terhadap produk tersebut. Keberadaan media sensorik suara seperti musik, dapat memberikan dampak positif dalam perilaku konsumsi/ pembelian dengan menciptakan sebuah asosiasi dan pembangkitan memori, terdapat korelasi positif antara musik dan waktu yang dihabiskan untuk berbelanja. Media-media yang mampu menstimulasi pemasaran melalui indera pendengaran adalah jingle, musik yang sesuai dengan ambiance ruang, dan brand signature sound. Media musik mampu menyampaikan mood dari karakter brand, dan lebih mencapai level emosional dibandingkan visual dan sentuhan. Wanita cenderung lebih menyukai musik yang lembut, sedangkan pria lebih menyukai musik yang lebih keras (Hulten, 2017). Pengalaman yang dirasakan oleh indera pengecapan penting juga untuk dipertimbangkan dengan rasa yang segar dan berrempah memberikan pengaruh positif yang ditunjukkan dengan konsumen akan menikmati suasana lebih lama.

Pengoptimalan kelima indera tersebut merupakan kunci dasar dari sebuah brand sensuality. Menurut Song et.al (2018) dalam penelitiannya mengenai lovemark theory dalam brand coffee shop, lovemark merupakan salah satu aspek yang berperan dalam meningkatkan loyalitas konsumen untuk sebuah brand. Lovemark ini terdiri dari faktor brand love dan brand respects. Brand respects terindikasi dari nilai kepercayaan konsumen terhadap brand (trust), brand reputation, dan brand performance. Sedangkan brand love akan terindikasi dari nilai brand mystery (bagaimana brand tersebut membuat penasaran), brand sensuality (bagaimana brand tersebut dapat dirasakan oleh kelima indera), dan brand intimacy (bagaimana membuat customer merasa akrab dengan brand tersebut). Menurut Rodrigues (2014), brand sensuality adalah sebuah kemampuan brandl perusahaan untuk menarik perhatian dan mengikutsertakan konsumen secara emosional melalui pelibatan kelima indera manusia ketika konsumen mengonsumsi barang dan jasa sebagai sebuah hasil dari pengalaman multi sensorik dari brand. Terdapat 3 aspek yang mempengaruhi nilai brand sensuality yakni isyarat sensorik sebagai sebuah input, persepsi konsumen secara sensorik, dan stimulasi multi sensorik dari produk dan jasa.

Dengan demikian brand sensuality sangat erat kaitannya dengan sistem pemasaran sensorik. Dalam penelitian yang dilakukan oleh Riza dan 
Wijayanti (2018), mengenai triangle of sensory marketing, membahas mengenai bagaimana model sistem pemasaran sensorik akan memberikan dampak pada brand experience yang dirasakan konsumen, yang kemudian pengalaman tersebut akan mempengaruhi loyalitas dari konsumen. Penelitian mereka dilakukan dengan dasar dari temuan oleh Brakus (dalam Riza \& Wijayanti, 2018) yaitu sebuah stimulus yang terkait dengan brand akan menggugah sensasi, perasaan, kognisi, dan respon secara perilaku sebagai bagian dari brand dan desain identitas, kemasan, komunikasi dan lingkungan, dan juga temuan dari Krishna (dalam Riza \& Wijayanti, 2018) bahwa sistem pemasaran yang melibatkan indera dari konsumen akan mempengaruhi persepsinya, penilaiannya dan juga perilakunya. Selain itu, strategi pemasaran dan lingkungan adalah dua hal yang penting untuk menyediakan stimulus. Dengan melihat temuan dari Brakus (dalam Rodrigues, 2014) yang mengungkapkan bahwa lingkungan juga merupakan bagian dari brand dan diperkuat oleh temuan dari Krishna (dalam Rodrigues, 2014), bahwa lingkungan merupakan salah satu bagian penting untuk menghadirkan stimulus dari brand, dapat disimpulkan bahwa lingkungan adalah salah satu media untuk mengukur tingkat brand sensuality dari sebuah produk dan jasa, dan juga sebagai media untuk sistem pemasaran multi sensorik. Semakin banyak stimulus sensorik positif yang ditampilkan pada produk dan jasa dari brand, persepsi konsumen terhadap brand akan semakin positif. Brand experience merupakan konseptualisasi dari sebuah sensasi, perasaan, kognisi dan perilaku konsumen sebagai respon dari stimulus-stimulus terkait brand, dan brand adalah kesatuan dari brand design dan identitas (nama dan logo), kemasan, komunikasi (iklan, brosur, website) dan lingkungan (desain toko, acara yang diselenggarakan), dan respon konsumen terhadap kesatuan brand ini disebut sebagai brand experience (Riza \& Wijayanti, 2018).

Dalam penelitian ini pula dijelaskan bahwa brand experience yang akan menentukan konsumen tersebut akan atau tidak akan merekomendasikan brand tersebut kepada orang lain. Selain itu, dijelaskan pula bahwa atribut sensorik yang dirasakan secara langsung dan intensitasnya kuat, akan mengakibatkan perubahan signifikan pada sikap dari konsumen, contohnya atribut sensorik dari musik dan pencahayaan yang terkombinasi untuk menciptakan atmosfer tertentu. Hasil dari penelitian tersebut adalah ketika brand menstimulasi indera, individu akan merasa nyaman, sehingga pikiran dan badannya akan mencoba untuk menerima stimulasi tersebut kembali, hal itu terus berulang sehingga akan menimbulkan loyalitas konsumen (Riza \& Wijayanti, 2018). Hal ini sesuai dengan hasil penelitian dari Song et.al (2018) bahwa brand love dan brand respect akan meningkatkan brand loyalty. Akan tetapi, kedua penelitian antara Riza \& Wijayanti (2018) dan Song et.al (2018) memiliki perbedaan fokus yang terkait loyalitas konsumen. Penelitian dari Song et.al (2018) melakukan fokus penelitian pada pengaruh brand love dan brand respect terhadap loyalitas, sedangkan Riza dan Wijayanti (2018) memfokuskan penelitian pada pengaruh brand experience terhadap loyalitas dengan sistem pemasaran secara sensorik memberikan pengaruh yang positif pada brand experience, dan brand experience memiliki pengaruh yang positif terhadap loyalitas konsumen. Pengalaman yang didapatkan dari sebuah brand (brand experience) seringkali melibatkan lingkungan fisik yang merepresentasikan brand tersebut. Faktor cahaya, warna dan musik memiliki andil/dampak yang besar dalam menentukan perilaku konsumen.

Terdapat empat dimensi dalam brand experience, yaitu Affective, Social, Behavioral dan Intellectual/ Cognitive (Riza \& Wijayanti, 2018). Affective terkait kepada emosi dan perasaan yang dirasakan konsumen terhadap brand, social terkait pada pengalaman untuk mengajak orang lain juga dalam merasakan experience yang sama. Behavioral terkait pada pengalaman fisik yang relevan dengan kehidupan konsumen, sedangkan intellectual/ cognitive melibatkan proses konsumen berpikir secara kreatif, dan bagaimana menciptakan sesuatu dengan cara yang berbeda. Berdasarkan penelitian dari Hulten (2017), stimulasi terhadap indera manusia melalui pemasaran secara sensorik akan menciptakan sebuah pengalaman yang memberi citra terhadap brand tersebut, yang bersifat personal, dalam level emosional, dengan gaya hidup, karakteristik personal dan konteks sosial menjadi pendorong utama. Dalam penelitian ini pula, Hulten (2017) memperkenalkan Sensory Branding Models (SBM). SBM merupakan penggabungan dari aspek societal culture, service environment, dan brand itu sendiri. Societal culture terkait dengan preferensi dari individu maupun kelompok, service environment terkait dengan bagaimana lingkungan menyediakan simbol-simbol sensorik yang terkait dengan preferensi tersebut, dan bagaimana brand dapat menuangkan identitas dan prinsip-prinsipnya dalam simbol-simbol sensorik tersebut. 


\section{Tinjauan Generasi Y dan Z}

Penelitian ini akan memfokuskan untuk menilai persepsi dari generasi $\mathrm{Y}$ dan $\mathrm{Z}$ yang dalam 10 tahun ke depan masih menjadi pelaku utama dalam kegiatan ekonomi. Menurut Jackson et.al (2011), generasi $\mathrm{Y}$ atau generasi milenial merupakan manusia yang lahir dalam periode tahun 1981 sampai dengan 1995. Generasi ini lahir dalam keadaan politik dan ekonomi yang stabil, sehingga mereka memiliki sifat-sifat yang cenderung berorientasi pada kenyamanan dan kemudahan, memiliki preferensi dan selera yang tinggi/ sophisticated. Sehingga apabila penelitian ini dilakukan pada tahun 2020, diperkirakan generasi $\mathrm{Y}$ ini adalah orang-orang yang memiliki usia antara 25-39 tahun. Berdasarkan hasil penelitian Susanti et.al. (2018), bahwa kriteria ruangan yang disukai oleh para milenial ini adalah aplikasi warna bersih dan menenangkan, adanya area restoratif, adanya privasi, dekat dengan alam, aplikasi bentuk-bentuk sederhana, fleksibel dan fungsional, extra space, dan sophisticated.

Sedangkan generasi $\mathrm{Z}$ disebut sebagai generasi post milenial yaitu manusia yang lahir pada tahun setelah 1995. Generasi Z umumnya sulit untuk memberikan atensi dalam waktu yang lama, sehingga segala sesuatu yang bersifat to the point akan lebih disukai, seperti karakter visual dengan prinsip "Less is More". Mereka cenderung menerima komunikasi dari orang-orang atau brand yang dapat dipercaya, kritis, tidak menyukai halhal yang terlalu mahal dan lumrah dengan demikian mereka sangat menyukai tampilan provokatif dan spektakuler. Pengalaman yang menyenangkan sangat penting bagi mereka, sehingga mereka cenderung egosentris, menolak masalah dan suka memberontak (Susanti \& Natalia, 2018).

Terkait dengan brand, menurut penelitian Hulten (2017) ditemukan bahwa konsumsi terhadap brand global merupakan hal yang penting bagi generasi $\mathrm{X}, \mathrm{Y}$, dan $\mathrm{Z}$ di negara-negara Australia, Brazil, China, India, Jepang, Swedia, UK, dan USA. Konsumsi brand tersebut membawa kepada pembentukan identitas dan citra diri yang baru. Proses konsumsi menjadi pembawa/carrier dari nilai-nilai personal untuk memuaskan ego dan kebutuhan untuk pemenuhan kebutuhan diri dalam hidup seperti kebahagiaan individu, khususnya untuk hal-hal yang terkait dengan kebutuhan fisik dan mental seseorang, seperti: makanan, lingkungan, fasilitas perawatan kesehatan, fasilitas bersenang-senang, rekreasi, keberlanjutan, fasilitas budaya dan edukasi.
Mengenai persepsi sensorik yang dirasakan oleh masing-masing individu, ternyata memiliki perbedaan apabila dilihat dari faktor internal dari manusia tersebut. Seperti misalnya untuk persepsi sensorik secara visual yang dimediakan dalam warna, desain, grafis, dan desain interior, terdapat perbedaan antara karakter dari responden Barat (Westerner) dan Asia Tenggara (South East Asian). Responden Barat cenderung untuk memberi perhatian lebih pada obyek secara keseluruhan, sedangkan responden Asia Tenggara lebih melihat detailnya. Oleh karena responden Asia Tenggara cenderung lebih detail dalam penglihatan, maka mereka lebih peka mendeteksi perubahan warna dan keluasan ruang. Faktor musik ternyata berkontribusi untuk pembentukan identitas bagi generasi X, Y, dan Z. Dalam persepsi sensorik olfaktori, ternyata faktor budaya juga memberikan pengaruh pada perbedaan persepsi, seperti aroma keju bagi responden Barat merupakan aroma yang menyenangkan, sedangkan bagi responden Asia Tenggara, aroma keju merupakan aroma yang tidak menyenangkan. Dalam budaya konsumsi global dengan generasi $\mathrm{X}, \mathrm{Y}$, dan $\mathrm{Z}$ sebagai kelompok segmentasi pasar, terbukti bahwa seseorang melibatkan lebih dari satu indera untuk mendapatkan pengalaman konsumsi pada sebuah brand (Hulten, 2017).

Berdasarkan hasil penelitian sebelumnya mengenai karakter ruang publik yang digemari oleh generasi $\mathrm{Z}$ Indonesia dengan responden asal Bali dan Bandung adalah fleksibel, unik, cukup memberikan privasi, dan kontemplatif. Karakter fleksibel ini adalah karakter sebuah ruang publik yang memungkinkan para generasi $\mathrm{Z}$ ini dapat melakukan lebih dari satu aktivitas. Munculnya jawaban shopping mall dan taman kota menunjukkan preferensi mereka terhadap ruang publik yang fleksibel, tidak dengan sekat yang masif, banyak aktivitas yang dapat dilakukan di tempat tersebut. Seperti pada shopping mall mereka dapat melakukan aktivitas berbelanja, makan, berfoto, berinteraksi dengan teman, menonton film. Demikian pula pada taman kota mereka dapat melakukan beberapa aktivitas seperti berdiskusi dan berinteraksi dengan teman, mengambil foto, sketsa, dan berolahraga. Karakter unik adalah karakter ruang publik yang mampu menghadirkan citra yang tidak lumrah, provokatif dan spektakuler. Hal ini akan mengundang generasi $\mathrm{Z}$ untuk mengabadikannya dalam foto. Karakter ruang publik yang dapat memberikan cukup privasi bagi generasi $\mathrm{Z}$ merupakan hal penting yang dipertimbangkan oleh anggota 
generasi Z. Seperti data yang telah didapat bahwa generasi $\mathrm{Z}$ cenderung lebih suka menghabiskan waktu mereka dengan teman yang sudah dikenal atau menghabiskan waktu mereka sendiri. Karakter kontemplatif yang dapat dihadirkan oleh suatu ruang publik menjadi pertimbangan penting bagi generasi $\mathrm{Z}$ karena mereka cenderung menyukai kegiatan kontemplatif yang dapat memberikan ketenangan dan inspirasi baru bagi mereka. Sehingga dalam ruang publik yang sangat kontemplatif mereka dapat melakukan kegiatan yang mengembangkan kreativitas mereka seperti sketsa, berolahraga, mengerjakan tugas kuliah, dan sebagainya (Susanti \& Natalia, 2018).

\section{METODE PENELITIAN}

Penelitian ini menggunakan metode sequential mixed-method (Creswell, 2014) berupa instrumen manusia dan instrumen angket/kuesioner. Instrumen manusia yang dimaksud adalah peneliti itu sendiri, yang dipergunakan untuk menentukan obyek-obyek coffee shop yang akan dijadikan area penelitian. Sedangkan instrumen berupa angket/kuesioner dipergunakan untuk memperoleh data responden, coffee shop favorit yang berada di area Kota Denpasar, dengan pengalaman sensorik mereka saat mengkonsumsi brand coffee shop favoritnya, serta loyalitas mereka terhadap coffee shop tersebut. Proses pengambilan data melalui media kuesioner ini bertujuan untuk mengetahui brand coffee shop apa saja yang dikenal dan paling disukai oleh responden generasi $\mathrm{Y}$ dan $\mathrm{Z}$ yang berada di Kota Denpasar, kegiatan apa saja yang biasa dilakukan, tingkat brand sensuality, brand experience dan loyalitas mereka terhadap coffee shop tersebut.

Instrumen penelitian disusun ke dalam 18 pertanyaan sebagai berikut :

Tabel 1. Daftar pertanyaan kuesioner

\begin{tabular}{|c|c|c|c|}
\hline No. & Variabel & Pertanyaan & $\begin{array}{c}\text { Model } \\
\text { Jawaban }\end{array}$ \\
\hline 1. & Brand love & $\begin{array}{l}\text { Apa coffee shop favorit } \\
\text { anda? }\end{array}$ & $\begin{array}{l}\text { Coffee shop } \\
\text { brand }\end{array}$ \\
\hline 2. & $\begin{array}{l}\text { Brand } \\
\text { experience }\end{array}$ & $\begin{array}{l}\text { Berapa lama anda } \\
\text { menghabiskan waktu } \\
\text { ketika datang ke coffee } \\
\text { shop tersebut? }\end{array}$ & $\begin{array}{l}\text { Kurang dari } 1 \\
\text { jam/ 1-3 jam/ } \\
\text { lebih dari } 3 \\
\text { jam }\end{array}$ \\
\hline 3. & Brand loyalty & $\begin{array}{l}\text { Berapa kali anda } \\
\text { mengunjungi } \\
\text { shop tersebut? }\end{array}$ & $\begin{array}{l}\text { Kurang dari } 2 \\
\text { kali/ 3-4 kali/ } \\
\text { Lebih dari } 4 \\
\text { kali }\end{array}$ \\
\hline 4. & $\begin{array}{l}\text { Brand } \\
\text { sensuality }\end{array}$ & $\begin{array}{l}\text { Aspek Visual : (; Hulten, } \\
\text { 2017; Riza \& Wijayanti, } \\
\text { 2018) } \\
\text { a. Apakah iklan tentang } \\
\text { coffee shop ini yang } \\
\text { menarik anda untuk } \\
\text { datang? } \\
\text { b. Apakah logo coffee }\end{array}$ & $\begin{array}{l}\text { Tidak - Ya ( } \\
\text { Semantic } \\
\text { Differencial } \\
\text { 1-5) }\end{array}$ \\
\hline
\end{tabular}

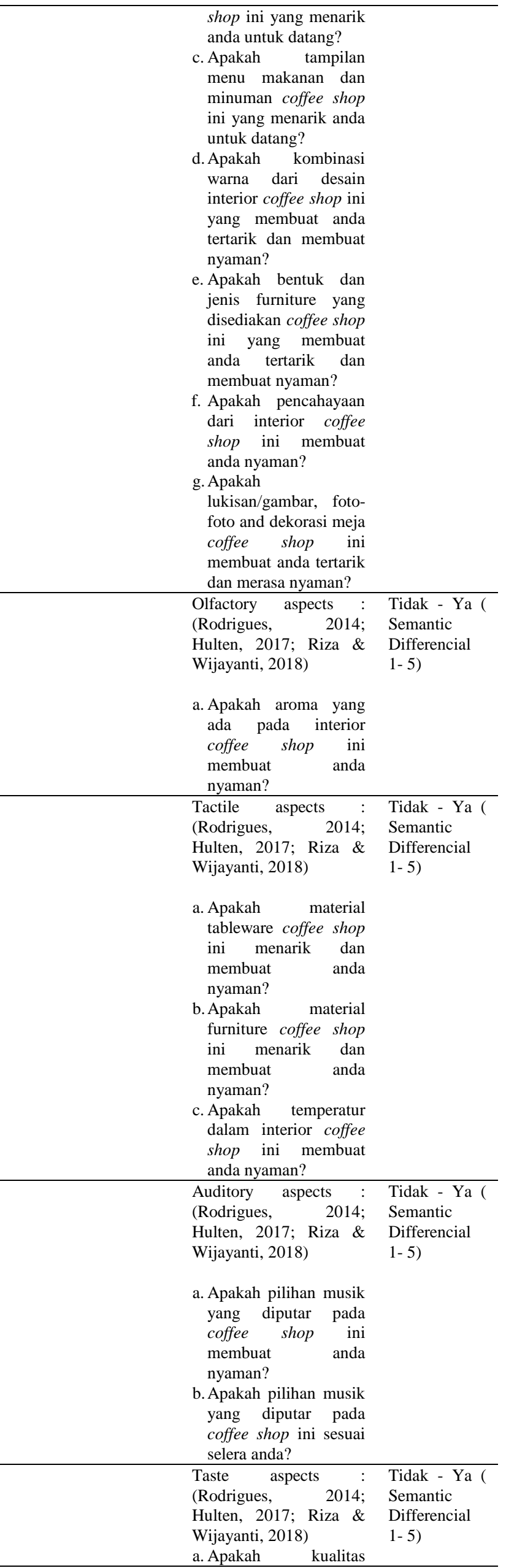


kopinya baik?

b. Apakah menu

makanan lain yang

disediakan

memuaskan anda?

Setelah data kuesioner terkumpul, data tersebut kemudian akan dianalisis korelasinya dengan brand experience dan brand loyalty melalui Analysis of Variance (ANOVA) menggunakan software JMP. Analisis tersebut bertujuan untuk melihat korelasi dari brand sensuality terhadap brand experience dan brand loyalty. Faktor-faktor brand sensuality apa saja yang menyebabkan brand experience yang positif ditandai dengan responden betah berada pada coffee shop yang mereka sukai.

Setelah data kuesioner tersebut dianalisis, kemudian akan dipilih 3-5 brand coffee shop yang disebutkan oleh responden dengan kriteria merupakan local brand di Denpasar untuk kemudian dilakukan observasi pada elemen-elemen interiornya dan melakukan wawancara pada beberapa konsumen yang sedang berada pada coffee shop tersebut, sehingga pada akhirnya akan dapat dipetakan keterkaitan antara pemilihan elemen-elemen desain interior, brand sensuality, dan loyalitas konsumen untuk coffee shop tersebut.

\section{PEMBAHASAN}

\section{Data Kuesioner Responden Generasi Z}

Kuesioner yang telah diisi oleh responden generasi $\mathrm{Z}$ berjumlah 100 kuesioner generasi Z, tetapi setelah diperiksa kembali usia dari responden pengisi kuesioner, ternyata data yang valid dari generasi $\mathrm{Z}$ berjumlah 74 kuesioner. Dari 74 responden tersebut memiliki rentang usia 16-25 tahun, didominasi oleh responden dengan usia 19 tahun sekitar 32,4\%, usia 20 tahun 24,3\%, dan usia 21 tahun sekitar 14,9\%. Komposisi responden dengan mayoritas usia tersebut menunjukkan pula bahwa responden sebagian besar adalah mahasiswa yang belum mandiri secara finansial, hal tersebut didukung oleh data pekerjaan responden yang $77 \%$ adalah mahasiswa, dan sisanya adalah pelajar sekolah menengah, freelancer, dan karyawan swasta.

Data kuesioner tersebut memunculkan 38 brand coffee shop yang menjadi favorit dari para responden. Hal ini menunjukkan bahwa bisnis coffee shop di Denpasar berkembang sangat pesat, terutama local coffee shop brand. Starbucks masih menjadi coffee shop favorit mayoritas responden sebanyak 36,8\% responden, sedangkan Samsara menjadi brand kedua yang dianggap favorit oleh
13,1 \%, diikuti oleh Nilo Coffee, Kopi Soe, Karakter Kopi, Jumping Stone Coffee, dan Janji Jiwa sebanyak masing-masing 10,5\%. Apabila dikategorikan, terdapat global chained coffee shop brand, national chained coffee shop brand, dan local coffee shop brand. Starbucks merupakan satu-satunya global chained coffee shop brand yang muncul sebagai coffee shop brand favorit dari responden generasi $\mathrm{Z}$ di Denpasar. Kemudian muncul national chained brand yaitu Kopi Soe, Janji Jiwa, dan Kulo, yang mulai muncul di Kota Denpasar sekitar awal tahun 2019, dengan munculnya nama-nama brand ini sebagai coffee shop favorit dari generasi $\mathrm{Z}$ di Denpasar, berarti brand kategori ini cukup berhasil untuk segmentasi generasi Z. Sisanya adalah local brand coffee shop yang cukup banyak disebutkan oleh responden generasi $\mathrm{Z}$.

Kegiatan yang umumnya para responden lakukan adalah bersosialisasi dengan teman, bekerja, menikmati kopi dan dessert favorit mereka, serta sebagian kecil hanya melakukan pemesanan take away, melakukan hobi mereka seperti menggambar, dan mengambil foto untuk diunggah ke media sosial mereka.

Apabila dilihat dari lamanya waktu yang mereka habiskan saat mengunjungi coffee shop favoritnya dengan berapa kali mereka sudah mengunjungi coffee shop tersebut, setelah dilakukan correspondency analysis didapatkan hasil bahwa semakin lama waktu yang mereka habiskan saat mengunjungi coffee shop, mereka juga cenderung lebih sering berkunjung kembali ke coffee shop tersebut.

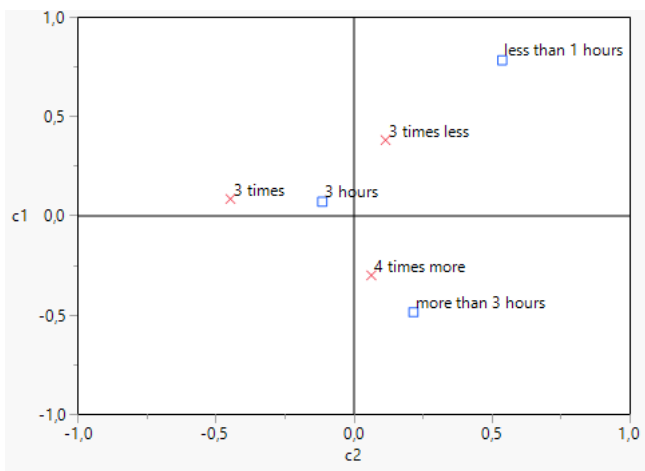

Gambar 1. Analisis korespondensi antara frekuensi kedatangan generasi $\mathrm{Z}$ dengan lama waktu yang dihabiskan saat kunjungan

Komponen-komponen brand sensuality yang dituangkan dalam pertanyaan mengenai stimulasi indera dari coffee shop favorit responden, dilakukan Principal Component Analysis (PCA) untuk mengetahui persepsi responden saat 
memahami pertanyaan-pertanyaan kuesioner. Hasil analisis PCA dengan eigen value di atas 7,5 memperlihatkan hasil bahwa terdapat dua kategori stimulasi yang dipersepsikan oleh responden, yaitu stimulasi non-visual yaitu suara, temperatur, tekstur dan jenis material furnitur, tableware, kualitas kopi dan makanan, serta daya tarik menu yang ditawarkan oleh coffee shop. Faktor lainnya adalah stimulasi visual, meliputi dekorasi interior, kombinasi warna, iklan, logo, bentuk furnitur dan pencahayaan.

Komponen-komponen ini kemudian akan dilihat korelasinya dengan waktu yang mereka habiskan saat berada di coffee shop dan jumlah kunjungan mereka ke coffee shop tersebut, hal tersebut dilihat pada tabel 2 dengan hasil sebagai berikut:

Tabel 2. Hasil ANOVA persepsi brand sensuality responden generasi $Z$ dengan lama kunjungan

\begin{tabular}{llccc}
\hline No. & $\begin{array}{l}\text { Stimulasi Non- } \\
\text { Visual }\end{array}$ & $\mathbf{< 1 j a m}$ & $\mathbf{1 - 2}$ jam & $>\mathbf{3}$ jam \\
\hline 1 & $\begin{array}{l}\text { Musik sesuai } \\
\text { selera }\end{array}$ & 3 & 3,94 & 3,94 \\
\hline 2 & $\begin{array}{l}\text { Musik yang } \\
\text { nyaman } \\
\text { didengar }\end{array}$ & 3,6 & 4 & 4,25 \\
\hline
\end{tabular}

\begin{tabular}{|c|c|c|c|c|}
\hline No. & $\begin{array}{c}\begin{array}{c}\text { Stimulasi non } \\
\text { visual }\end{array} \\
\end{array}$ & 1-2 kali & 3-4 kali & 4 kali < \\
\hline 1 & $\begin{array}{l}\text { Musik sesuai } \\
\text { selera }\end{array}$ & 3,65 & 3,92 & 4,03 \\
\hline 2 & $\begin{array}{l}\text { Musik yang } \\
\text { nyaman didengar }\end{array}$ & 3,85 & 4 & 4,17 \\
\hline 3 & $\begin{array}{l}\text { Temperatur } \\
\text { interior }\end{array}$ & 4,12 & 4 & 4,03 \\
\hline 4 & Tekstur furniture & 3,92 & 4 & 4,03 \\
\hline 5 & Tableware & 3,96 & 4,42 & 4,14 \\
\hline 6 & Kualitas kopi & 4,42 & 3,67 & 4,42 \\
\hline 7 & Material furniture & 3,88 & 4,42 & 4,11 \\
\hline 8 & $\begin{array}{l}\text { Menu makanan } \\
\text { yang memuaskan }\end{array}$ & 3,96 & 4,25 & 4 \\
\hline 9 & Aroma interior & 4,27 & 4,25 & 4,47 \\
\hline 10 & $\begin{array}{l}\text { Penyajian } \\
\text { makanan dan } \\
\text { minuman yang } \\
\text { menarik }\end{array}$ & 3,8 & 4,04 & 3,81 \\
\hline 3 & $\begin{array}{l}\text { Temperatur } \\
\text { interior }\end{array}$ & 4 & 4,04 & 4,13 \\
\hline 4 & $\begin{array}{l}\text { Tekstur } \\
\text { furniture }\end{array}$ & 3,6 & 4,06 & 3,88 \\
\hline 5 & Tableware & 3,6 & 4,17 & 4,13 \\
\hline 6 & Kualitas kopi & 4,4 & 4,28 & 4,31 \\
\hline 7 & $\begin{array}{l}\text { Material } \\
\text { furniture }\end{array}$ & 3,8 & 4,1 & 4,13 \\
\hline 8 & $\begin{array}{l}\text { Menu makanan } \\
\text { yang } \\
\text { memuaskan }\end{array}$ & 4 & 4,11 & 3,75 \\
\hline 9 & Aroma interior & 4,2 & 4,3 & 4,63 \\
\hline
\end{tabular}

\begin{tabular}{clccc}
\hline \multicolumn{1}{c}{ Penyajian } & & & \\
& $\begin{array}{l}\text { makanan dan } \\
\text { minuman yang } \\
\text { menarik }\end{array}$ & 3,8 & 4,04 & 3,81 \\
\hline No. & $\begin{array}{l}\text { Stimulasi } \\
\text { Visual }\end{array}$ & $<\mathbf{j a m}$ & $\begin{array}{c}\mathbf{1 - 2} \\
\text { jam }\end{array}$ & $>\mathbf{3}$ jam \\
\hline 1 & $\begin{array}{l}\text { Dekorasi } \\
\text { Interior }\end{array}$ & 3,4 & 3,83 & 3,75 \\
\hline 2 & $\begin{array}{l}\text { Warna } \\
\text { Interior }\end{array}$ & 4,2 & 4,2 & 4,5 \\
\hline 3 & $\begin{array}{l}\text { Iklan yang } \\
\text { menarik }\end{array}$ & 3,6 & 3,4 & 3,56 \\
\hline 4 & $\begin{array}{l}\text { Logo yang } \\
\text { menarik }\end{array}$ & 4,2 & 3,7 & 3,5 \\
\hline 5 & $\begin{array}{l}\text { Bentuk } \\
\text { furniture }\end{array}$ & 3,6 & 4,11 & 4,13 \\
\hline 6 & $\begin{array}{l}\text { Pencahayaan } \\
\text { interior }\end{array}$ & 4,2 & 4,13 & 4,44 \\
\hline
\end{tabular}

Berdasarkan hasil pada tabel 2, dapat dilihat bahwa bila responden bersedia menghabiskan waktu yang lama pada coffee shop (lebih dari 3 jam), maka coffee shop harus dapat memberi stimulasi nonvisual pada faktor suara/ musik yang nyaman didengar, temperatur ruang yang nyaman, material furnitur yang membuat nyaman, kualitas kopi yang baik, dan menghadirkan aroma yang menyenangkan, serta harus memberi stimulasi visual yang positif pada kombinasi warna interior, bentuk furnitur dan pencahayaan pada interiornya.

Hal serupa juga terlihat dari korelasi antara frekuensi responden berkunjung kembali ke coffee shop favoritnya dengan nilai brand sensuality coffee shop yang diuraikan dalam stimulasi inderaindera yang disediakan oleh lingkungannya. Tabel 3 menunjukkan bahwa responden cenderung akan sering berkunjung kembali apabila mereka mendapatkan stimulasi yang positif dalam hal suara atau musik yang nyaman untuk didengar, memiliki kualitas kopi yang baik, temperatur ruang yang nyaman, tekstur furnitur nyaman dan menghadirkan aroma yang menyenangkan dalam stimulasi non-visual, serta harus memberi stimulasi visual pada kombinasi warna, bentuk furnitur dan pencahayaan interiornya.

Tabel 3. Hasil ANOVA persepsi brand sensuality responden generasi $\mathrm{Z}$ dengan frekuensi kunjungan

\begin{tabular}{llccc}
\hline No. & Stimulasi visual & $\mathbf{1 - 2}$ kali & $\mathbf{3 - 4}$ kali & $\mathbf{4}$ kali < \\
\hline 1 & Dekorasi Interior & 3,62 & 4 & 3,83 \\
\hline 2 & Warna Interior & 4,23 & 4,42 & 4,22 \\
\hline 3 & $\begin{array}{l}\text { Iklan yang } \\
\text { menarik }\end{array}$ & 3,27 & 3,33 & 3,61 \\
\hline 4 & $\begin{array}{l}\text { Logo yang } \\
\text { menarik }\end{array}$ & 3,77 & 3,92 & 3,53 \\
\hline 5 & Bentuk furniture & 4,12 & 4,08 & 4,06 \\
\hline 6 & $\begin{array}{l}\text { Pencahayaan } \\
\text { interior }\end{array}$ & 4,08 & 4,25 & 4,28 \\
\hline
\end{tabular}




\section{Data Kuesioner Responden Generasi Y}

Kuesioner yang telah diisi oleh responden generasi $\mathrm{Y}$ berjumlah 72 kuesioner generasi $\mathrm{Y}$, tetapi setelah diperiksa kembali usia dari responden pengisi kuesioner, ternyata data yang valid dari generasi $\mathrm{Y}$ berjumlah 52 kuesioner. Dari 52 responden tersebut memiliki rentang usia 26-39 tahun, didominasi oleh responden dengan usia 26 tahun sekitar 36,5\%, usia 27-29 tahun 38,5\%, usia 30-35 tahun 28,9\%, dan sisanya responden usia di atas 35 tahun sebanyak 3,8\%. Komposisi responden generasi Y didominasi oleh pekerja swasta/ karyawan swasta sebanyak 34,6 \%, kemudian arsitek 13,5\%, wiraswasta 9,6\%, dosen $7,7 \%$, ibu rumah tangga, guru, graphic designer, fotografer, dan dokter masing-masing sebanyak $5,8 \%$, desainer interior 3,9\% lalu web developer, ilustrator, freelancer, desainer dan barista masingmasing sebanyak 1,9\%. Berbeda dengan kelompok generasi $\mathrm{Z}$ yang sebagian besar belum mandiri secara finansial, kelompok generasi $\mathrm{Y}$ merupakan kelompok responden yang telah mandiri secara finansial (telah memiliki penghasilan sendiri). Data kuesioner dari responden generasi Y memunculkan 30 brand coffee shop yang menjadi favorit dari para responden. Beberapa nama brand yang juga telah muncul pada data responden generasi $\mathrm{Z}$ juga muncul pada data responden generasi $\mathrm{Y}$ seperti Starbucks yang juga menjadi brand dengan frekuensi penyebutan yang paling banyak sekitar $25 \%$ responden yang menyebutkan, kemudian Karakter Kopi, Hanaka Kopi, Nilo, Simply Brew, Point Coffee dan Bhineka Djaja. Hanya saja perbedaan yang muncul dari data responden generasi Y adalah tidak ada national chained coffee shop brand seperti Janji Jiwa, Kopi Soe, dan Kulo yang seringkali produknya disebut sebagai kopi kekinian, yang disebutkan responden generasi Y sebagai coffee shop favorit mereka.

Kegiatan generasi $\mathrm{Y}$ yang umumnya dilakukan pada coffee shop didominasi dengan bersosialisasi dengan teman diikuti dengan kegiatan bekerja, menikmati kopi, dessert, dan sebagian kecil hanya melakukan pemesanan take away. Serta, melakukan hobi mereka seperti otomotif, bertemu klien, bersantai atau sekadar menikmati desain interior coffee shop dan juga untuk mencari inspirasi. Apabila dilihat dari lamanya waktu dihabiskan saat mengunjungi coffee shop favoritnya dengan berapa kali mereka sudah mengunjungi coffee shop tersebut, setelah dilakukan correspondency analysis didapatkan pola yang serupa dengan hasil correspondency analysis yang didapatkan dari data responden generasi Z, dengan rata-rata responden yang menyatakan mengunjungi coffee shop favoritnya lebih dari empat kali, cenderung menghabiskan waktu yang lama di coffee shop tersebut pada setiap kunjungannya (gambar 2).

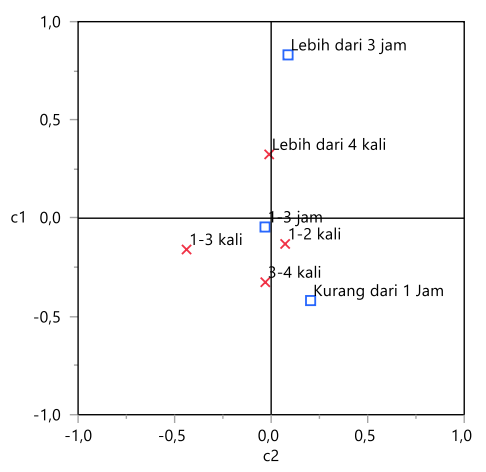

Gambar 2. Analisis korespondensi antara frekuensi kedatangan generasi $Y$ dengan lama waktu yang dihabiskan saat kunjungan

Komponen-komponen brand sensuality dituangkan dalam pertanyaan mengenai stimulasi indera dari coffee shop favorit responden, kemudian dilakukan Principal Component Analysis (PCA) untuk mengetahui persepsi responden saat memahami pertanyaan-pertanyaan kuesioner. Hasil analisis PCA dengan eigen value di atas 7,5 memperlihatkan hasil bahwa terdapat dua kategori stimulasi yang dipersepsikan oleh responden yaitu stimulasi non-visual yaitu menu/makanan, kualitas kopi, tekstur dan jenis material furnitur, tableware, aroma yang mendominasi coffee shop, musik yang sesuai selera responden, serta periklanan dari coffee shop. Faktor lainnya adalah stimulasi visual, meliputi dekorasi interior, kombinasi warna, logo, bentuk furnitur, temperatur, musik yang nyaman, dan pencahayaan. Hasil pengelompokan ini sedikit berbeda dengan hasil PCA yang didapatkan dari data responden generasi $\mathrm{Z}$.

Komponen-komponen ini kemudian akan dilihat korelasinya dengan waktu yang dihabiskan saat berada di coffee shop dan jumlah kunjungan mereka ke coffee shop tersebut, hal tersebut dilihat pada tabel 4 dengan hasil sebagai berikut:

Tabel 4. Hasil ANOVA persepsi brand sensuality responden generasi Y dengan lama kunjungan

\begin{tabular}{llccc}
\hline No. & $\begin{array}{c}\text { Stimulasi non } \\
\text { visual }\end{array}$ & $\mathbf{< 1 j a m}$ & $\mathbf{1 - 2}$ jam & $>\mathbf{3}$ jam \\
\hline 1 & $\begin{array}{l}\text { Menu makanan } \\
\text { yang memuaskan }\end{array}$ & 4,20 & 3,98 & 4,60 \\
\hline 2 & Kualitas kopi & 4,60 & 4,24 & 4,60 \\
\hline 3 & Tekstur furniture & 4,00 & 3,89 & 3,80 \\
\hline 4 & Tableware & 4,00 & 3,91 & 4,40 \\
\hline 5 & $\begin{array}{l}\text { Penyajian } \\
\text { makanan dan }\end{array}$ & 4,20 & 3,78 & 5,00 \\
\hline
\end{tabular}




\begin{tabular}{|c|c|c|c|c|}
\hline & $\begin{array}{l}\text { minuman yang } \\
\text { menarik }\end{array}$ & & & \\
\hline 6 & Aroma interior & 4,20 & 4,26 & 4,60 \\
\hline 7 & $\begin{array}{l}\text { Musik sesuai } \\
\text { selera }\end{array}$ & 3,60 & 3,54 & 4,00 \\
\hline 8 & Material furniture & 4,00 & 3,95 & 4,60 \\
\hline 9 & $\begin{array}{l}\text { Iklan yang } \\
\text { menarik }\end{array}$ & 3,20 & 3,63 & 4,20 \\
\hline No. & $\begin{array}{l}\text { Visual } \\
\text { Stimulation } \\
\text { Factors }\end{array}$ & $<1$ jam & 1-2 jam & $>3$ jam \\
\hline 1 & $\begin{array}{l}\text { Pencahayaan } \\
\text { interior }\end{array}$ & 3,60 & 4,24 & 4,80 \\
\hline 2 & $\begin{array}{l}\text { Musik yang } \\
\text { nyaman didengar }\end{array}$ & 4,40 & 3,87 & 4,60 \\
\hline 3 & Bentuk furniture & 3,60 & 4,09 & 4,60 \\
\hline 4 & Dekorasi Interior & 4,20 & 4,00 & 4,60 \\
\hline 5 & Warna Interior & 4,00 & 4,09 & 4,80 \\
\hline 6 & $\begin{array}{l}\text { Temperatur } \\
\text { interior }\end{array}$ & 4,00 & 4,04 & 4,20 \\
\hline 7 & $\begin{array}{l}\text { Logo yang } \\
\text { menarik }\end{array}$ & 3,20 & 3,20 & 3,60 \\
\hline
\end{tabular}

Berdasarkan hasil ANOVA tersebut, dapat dilihat bahwa bila responden bersedia menghabiskan waktu yang lama pada coffee shop (lebih dari 3 jam), maka coffee shop harus dapat memberi stimulasi non-visual pada menu makanan yang memuaskan, kualitas kopi, penyajian menu yang menarik, kualitas perangkat makan dan minum (gelas, piring, sendok, dan lain-lain), aroma yang dihadirkan dalam ruangan, suara-suara atau musik yang sesuai selera responden, material furnitur, dan juga iklan-iklan yang disajikan oleh coffee shop pada media sosial. Sisi stimulasi visual yang berpengaruh terhadap waktu yang dihabiskan pada coffee shop pencahayaan ruangan, suara yang menyamankan telinga, bentuk furnitur, dekorasi, warna dan temperatur interior.

Hal yang cukup berbeda terlihat dari korelasi antara frekuensi responden berkunjung kembali ke coffee shop favoritnya dengan nilai brand sensuality coffee shop yang diuraikan dalam stimulasi indera-indera yang disediakan oleh lingkungannya. Sesuai dengan hasil dalam tabel 5, bahwa responden cenderung akan sering berkunjung kembali apabila mereka mendapatkan stimulasi yang positif dalam hal suara atau musik yang nyaman untuk didengar, kualitas kopi yang baik, temperatur ruang yang nyaman, aroma yang menyenangkan dan material furnitur dalam stimulasi non-visual, serta harus memberi stimulasi visual pada kombinasi warna, bentuk furnitur, pencahayaan, dekorasi, dan temperatur interiornya.

Tabel 5. Hasil ANOVA persepsi brand sensuality responden generasi $\mathrm{Y}$ dengan frekuensi kunjungan

\begin{tabular}{|c|c|c|c|c|c|}
\hline No. & $\begin{array}{c}\text { Stimulasi non- } \\
\text { visual }\end{array}$ & 1-2 kali & $\begin{array}{l}1-3 \\
\text { kali }\end{array}$ & $\begin{array}{l}3-4 \\
\text { kali }\end{array}$ & 4 kali< \\
\hline 1 & $\begin{array}{l}\text { Menu makanan } \\
\text { yang memuaskan }\end{array}$ & 4,13 & 5,00 & 3,94 & 4,04 \\
\hline 2 & Kualitas kopi & 4,38 & 2,59 & 4,25 & 4,30 \\
\hline 3 & Tekstur furniture & 3,94 & 3,00 & 3,88 & 3,91 \\
\hline 4 & Tableware & 3,87 & 3,00 & 3,75 & 4,28 \\
\hline 5 & $\begin{array}{l}\text { Penyajian } \\
\text { makanan dan } \\
\text { minuman yang } \\
\text { menarik }\end{array}$ & 3,94 & 3,00 & 3,69 & 4,13 \\
\hline 6 & Aroma interior & 4,31 & 3,00 & 4,19 & 4,39 \\
\hline 7 & $\begin{array}{l}\text { Musik sesuai } \\
\text { selera }\end{array}$ & 3,25 & 4,00 & 3,81 & 3,65 \\
\hline 8 & Material furniture & 3,94 & 3,00 & 3,88 & 4,22 \\
\hline 9 & $\begin{array}{l}\text { Iklan yang } \\
\text { menarik }\end{array}$ & 3,56 & 3,00 & 3,67 & 3,69 \\
\hline No. & Stimulasi Visual & $\begin{array}{c}1-2 \\
\text { kali }\end{array}$ & $\begin{array}{r}1-3 \\
\text { kali }\end{array}$ & $\begin{array}{l}3-4 \\
\text { kali } \\
\end{array}$ & 4 kali< \\
\hline 1 & $\begin{array}{l}\text { Pencahayaan } \\
\text { interior }\end{array}$ & 4,38 & 3,00 & 4,00 & 4,35 \\
\hline 2 & $\begin{array}{l}\text { Musik yang } \\
\text { nyaman didengar }\end{array}$ & 3,88 & 3,00 & 4,13 & 4,00 \\
\hline 3 & Bentuk furniture & 4,38 & 3,00 & 3,75 & 4,17 \\
\hline 4 & Dekorasi Interior & 4,38 & 3,00 & 3,94 & 4,00 \\
\hline 5 & Warna Interior & 4,25 & 3,00 & 4,00 & 4,22 \\
\hline 6 & $\begin{array}{l}\text { Temperatur } \\
\text { interior }\end{array}$ & 4,06 & 3,00 & 4,06 & 4,09 \\
\hline 7 & $\begin{array}{l}\text { Logo yang } \\
\text { menarik }\end{array}$ & 3,19 & 3,00 & 3,06 & 3,39 \\
\hline
\end{tabular}

Adapun beberapa hasil pengolahan data yang cukup unik untuk data responden generasi Y, ada beberapa faktor brand sensuality yang memiliki korelasi tinggi dengan faktor lainnya. Salah satunya adalah faktor pencahayaan yang memiliki nilai korelasi positif yang tinggi (di atas 0,5 ) dengan beberapa faktor pada tabel di bawah ini:

Tabel 6. Faktor yang berkorelasi tinggi dengan pencahayaan interior

\begin{tabular}{clc}
\hline No. & \multicolumn{1}{c}{ Faktor } & Nilai korelasi \\
\hline 1 & Material furniture & 0,58 \\
\hline 2 & Tableware & 0,61 \\
\hline 3 & Tekstur furnitur & 0,52 \\
\hline 4 & Dekorasi interior & 0,61 \\
\hline 5 & Bentuk furniture & 0,81 \\
\hline 6 & Warna interior & 0,64 \\
\hline
\end{tabular}

Faktor lainnya adalah faktor dekorasi interior yang memiliki korelasi positif yang tinggi di atas 0,50 dengan faktor-faktor di bawah ini :

Tabel 7. Faktor yang berkorelasi tinggi dengan dekorasi interior 


\begin{tabular}{clc}
\hline No. & \multicolumn{1}{c}{ Faktor } & Nilai korelasi \\
\hline 1 & Bentuk furniture & 0,67 \\
\hline 2 & Warna interior & 0,76 \\
\hline 3 & $\begin{array}{l}\text { Penyajian makanan dan } \\
\text { minuman yang menarik }\end{array}$ & 0,58 \\
\hline 4 & Tableware & 0,61 \\
\hline 5 & Tekstur furniture & 0,51 \\
\hline 6 & Temperatur interior & 0,53 \\
\hline
\end{tabular}

Berdasarkan tabel 7 faktor dekorasi juga memiliki korelasi positif yang tinggi dengan faktor temperatur dengan nilai korelasi sebesar 0,53. Faktor tableware dan kemenarikan dari sajian menu (food and beverage attractive) juga memiliki korelasi positif tinggi sebesar 0,61. Selain data yang ditampilkan pada tabel 6 dan 7, hasil analisis korelasi antar faktor juga menunjukkan menu makanan yang memuaskan (satisfying menu) juga berkorelasi tinggi dengan kemenarikan sajian menu sebesar 0,58, serta faktor kualitas kopi berkorelasi tinggi dengan kualitas menu makanan sebesar 0,51 dan aroma dari ruangan (interior scents) sebesar 0,52.

\section{Observasi pada beberapa Coffee Shop di Denpasar}

Pemilihan lokasi coffee shop dilakukan oleh Peneliti dengan mengesampingkan brand-brand coffee shop yang merupakan global chained brand seperti Starbucks, franchise dan national chained brand seperti Point Coffee, Kene Keto Coffee, Kulo, Janji Jiwa, dan Kopi Soe. Pemilihan lokasi observasi juga melibatkan ahli yaitu salah satu owner coffee shop yang bernama Bapak Putu Wiyoga sehingga brand-brand coffee shop yang muncul dari data responden generasi $\mathrm{Y}$ dan $\mathrm{Z}$ dikelompokkan dalam tiga kategori yaitu Product Concern, Product Interior Concern, dan Interior Concern.

Kategori Product Concern ditujukan untuk mengelompokkan brand-brand coffee shop yang lebih mengutamakan produk atau menu dari coffee shop dibandingkan desain interiornya, sedangkan kategori Product Interior Concern untuk mengelompokkan coffee shop yang memperhatikan produk/menu coffee shop serta desain interior dari coffee shop tersebut. Kategori ketiga adalah kategori Interior Concern ditujukan untuk mengelompokkan brand coffee shop yang mengutamakan desain interior dibanding produk/menunya. Detail pengkategorian brand coffee shop dianalisis oleh penulis dan narasumber ahli, Putu Wiyoga, tertuang dalam tabel berikut ini:
Tabel 8. Pengkategorian coffee shop

\begin{tabular}{ccc}
\hline Product Main Concern & $\begin{array}{c}\text { Product \& } \\
\text { Interior Concern }\end{array}$ & Interior Concern \\
\hline Bhineka Djaja & Humble Espresso & Nilo \\
\hline Jenar & Voltvet & $09 / 11$ concept store \\
\hline Aboe Talib & Second Floor & Hanaka Coffee \\
\hline Simply Brew & Coffee Secret & Alleway \\
\hline Kopi Made & $\begin{array}{c}\text { Khayal Coffee } \\
\text { Studio }\end{array}$ & Milestone \\
\hline Kopi Satu & Revayah & Latte'O \\
\hline Kopi Rumahan & & Basic Coffee \\
\hline Toko Kopi Damar & & One Day Coffee \\
\hline Mitos Kopi & & Limamike Coffee \\
\hline Renon/Arjuna & & Trilogy \\
\hline Karakter Kopi & & The Hub \\
\hline Ruang Kopi & & Sala Bistro \\
\hline & & 20 ml \\
\hline & & Loh Coffee Shop \\
\hline
\end{tabular}

Berdasarkan pengkategorian pada tabel 8 , Peneliti melakukan observasi pada lima brand coffee shop yaitu Jenar dan Coffee Secret dari kategori Product and Interior Concern, kemudian Alleway dan Milestone dari kategori Interior Concern. Dalam proses observasi ini, Peneliti melakukan wawancara dengan owner/manajer coffee shop, serta wawancara dengan beberapa konsumen yang sedang berada pada coffee shop tersebut.

\section{Jenar Coffee}

Berdasarkan hasil wawancara Peneliti dengan pemilik/owner dari Jenar yaitu Mas Munir, Jenar berdiri secara resmi pada tanggal 5 Juli 2017. Jenar merupakan local brand coffee shop yang didirikan untuk segmentasi pasar penikmat kopi golongan muda dari usia 17-35 tahun, menyediakan kopi berkualitas baik tapi dengan harga yang terjangkau. Komedi atau kejenakaan merupakan strategi dalam membangun brand Jenar di masyarakat sehingga mampu mendekatkan brand Jenar di hati pelanggannya. Desain interior dari Jenar, merupakan ide dari sang pemilik yang mengangkat konsep imajinasi dan fantasi. Jenar mengangkat konsep sebagai sebuah coffee shop yang mampu mengakrabkan diri dengan pelanggan-pelanggannya.

Sebagai salah satu studi kasus dari brand coffee shop kategori Product Concern, desain interior yang dihadirkan pada coffee shop ini memang terlihat sederhana dan dibiarkan apa adanya. Dalam upaya untuk menyediakan kenyamanan bagi 
konsumen, pencahayaan menjadi elemen interior yang diutamakan untuk menghadirkan suasana ruang yang hangat, kenyamanan lainnya lebih banyak diberikan melalui keramahan dan keakraban antara konsumen dan baristanya. Hal ini disebutkan dalam beberapa hasil wawancara dengan konsumen Jenar.

Frekuensi dan lama kunjungan dari konsumenkonsumen yang diwawancara rata-rata mereka hampir enam hari dalam seminggu mengunjungi Jenar. Dapat dikatakan bahwa konsumenkonsumen Jenar sebagian adalah konsumen dengan loyalitas yang tinggi terhadap brand Jenar. Seperti Angga (24 tahun), mengatakan sudah menjadi pelanggan Jenar sejak 2017, dalam sehari bisa melakukan dua kali kunjungan, dan dalam seminggu bisa mengunjungi Jenar lima hari berturut-turut. Pelanggan lainnya Yos, bahkan dalam sehari bisa mengunjungi Jenar 2-3 kali hampir sama dengan Yos, Palel juga melakukan kunjungan ke Jenar enam hari dalam seminggu, dan dua kali kunjungan tiap harinya. Rata-rata konsumen Jenar yang memiliki loyalitas tinggi menyukai kesederhanaan interior Jenar, sehingga lingkungan sosialnya dianggap bersahabat sehingga memudahkan mereka untuk bersosialisasi dengan orang baru, seperti barista ataupun konsumen lainnya, serta harga menunya yang terjangkau.

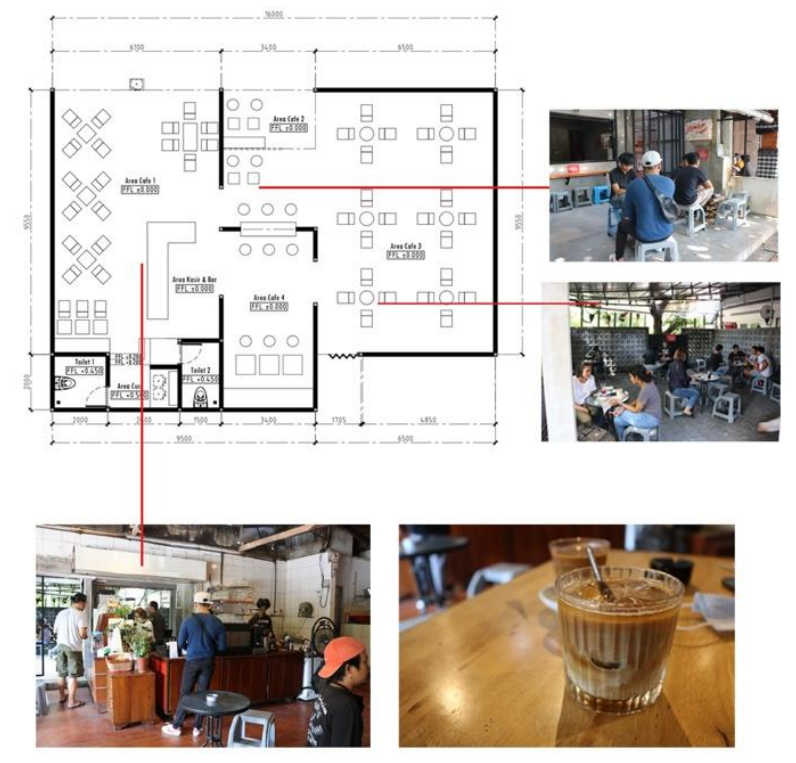

Gambar 3. Lingkungan dan kondisi dari Coffee Shop Jenar

\section{Simply Brew}

Berdasarkan hasil wawancara Peneliti dengan pemilik coffee shop Simply Brew, Vivi Sofia, pada awalnya Simply Brew bukan coffee shop tetapi merupakan coffee roastery. Berawal dari konsep tempat untuk me-roasting biji kopi dengan keinginan untuk menghasilkan biji-biji kopi terbaik, sehingga tercipta nama Simply Brew yang bisa menyediakan bahan-bahan hasil roasting kopi terbaik. Dengan konsep awal yang merupakan specialty coffee, segmen pasar mereka adalah para penikmat kopi. Dengan mengambil lokasi di kawasan Sanur, justru pelanggan lokal lebih banyak daripada wisatawan. Sebelum pandemi terjadi, Simply Brew ramai pengunjung pada waktu tertentu, seperti di pagi hari pada pukul 8-10 dan di siang hari pada pukul 2-4 sore. Mereka hanya buka mulai pukul 8.00-17.00.

Dalam hal branding, Simply Brew sangat sedikit melakukan iklan lewat media sosial. Mereka hanya mengandalkan iklan dari mulut ke mulut dan lebih memfokuskan pelayanan yang ramah kepada konsumen. Sehingga konsumen bisa menikmati produk, perusahaan, atmosfer yang positif. Interiornya tidak memiliki desain yang spesial tapi mereka bekerja sama dengan owner Bali Foodies. Bali Foodies memberikan banyak masukan untuk interior Simply Brew. Gaya interior yang digunakan lebih mengarah ke industrial tapi dengan tampilan yang lebih bersih dengan dominasi warna putih dan coklat.

Sebagai sebuah specialty coffee, Simply Brew menyajikan dua mesin kopi pada lantai satu dan lantai dua. Konsumen yang berhasil diwawancarai adalah konsumen berusia 39 tahun (generasi Y) dan konsumen berusia 49 tahun (generasi X). Mereka merupakan pelanggan lama Simply Brew. Hal yang membuat mereka memiliki loyalitas dengan Simply Brew adalah kualitas produk, terutama kopi yang disajikan, memiliki kualitas yang baik. Meskipun dari segi desain interiornya mereka anggap biasa saja, tapi aroma kopi yang mendominasi ruangan sangat menyenangkan. 


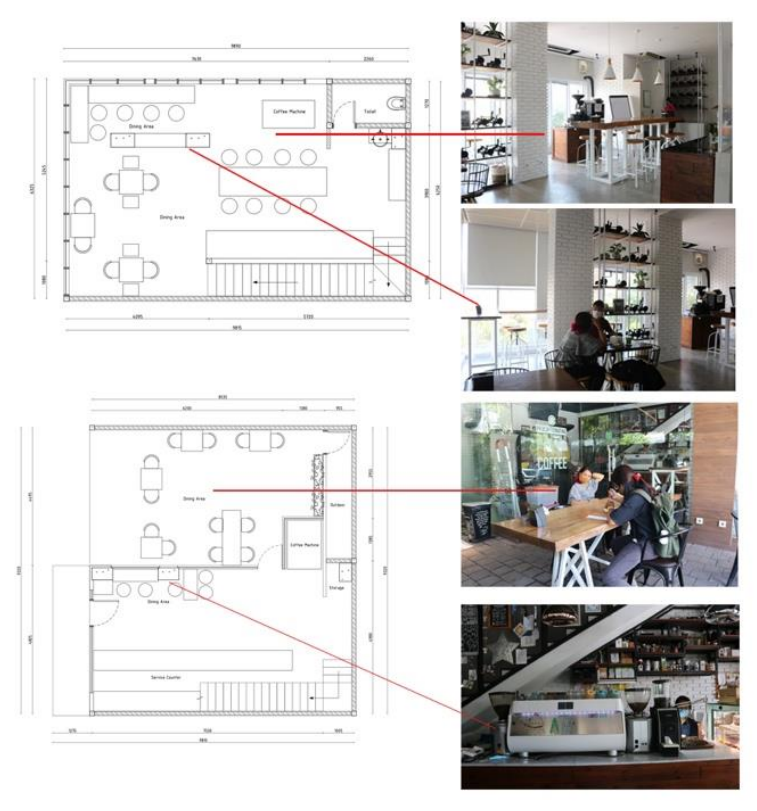

Gambar 4. Lingkungan dan kondisi dari Coffee Shop Simply Brew

\section{Coffee Secret's}

Coffee shop Coffee Secret's dibuka sejak Desember 2012. Segmentasi pasar yang dituju awalnya untuk umum dari segala kalangan. Namun, seiring berjalannya waktu, segmentasi pasar Coffee Secret's akhirnya terbentuk yaitu untuk kalangan professional muda maupun yang lebih dewasa. Oleh karena tanggapan masyarakat yang positif, Coffee Secret's akhirnya menyediakan ruang meeting bagi yang membutuhkan ruangan untuk meeting di luar kantor. Waktu-waktu yang ramai pengunjung adalah saat jam kerja dan hari kerja. Sebelum terjadinya pandemi, rata-rata konsumen adalah pekerja, sehingga perubahan saat pandemi sangat terasa penurunannya, namun perlahan sudah mulai bangkit dan naik kembali.

Strategi branding yang dilakukan saat ini adalah dengan mengandalkan konsumen lama dan pemasaran dari mulut ke mulut, karena Coffee Secret's memang dirancang bagi yang ingin bekerja di luar rumah atau di luar kantor. Media sosial untuk Coffee Secret's bahkan kurang diperbaharui. Konsep desain interior Coffee Secret's ini memang dicetuskan pemilik, tapi penyempurnaan desain dibantu oleh arsitek. Konsep desain interior Coffee Secret's adalah homy seperti di rumah, nyaman, tetapi tetap memiliki privasi.

Desain interior yang dihadirkan oleh Coffee Secret's didominasi oleh warna-warna kayu dilengkapi dengan warna pencahayaan warm white yang memberi kesan hangat pada ruangan, dengan desain kontemporer. Variasi furnitur yang cukup beragam juga memudahkan konsumen untuk memilih tempat duduk sesuai dengan tujuannya datang ke coffee shop ini. Sebagian besar pelanggan loyalnya seperti Panji (23 tahun) dan Mia (28 tahun) menyukai coffee shop ini dari sisi desain interiornya yang kekinian, nyaman untuk bekerja, dan juga tetap menjaga privasi.

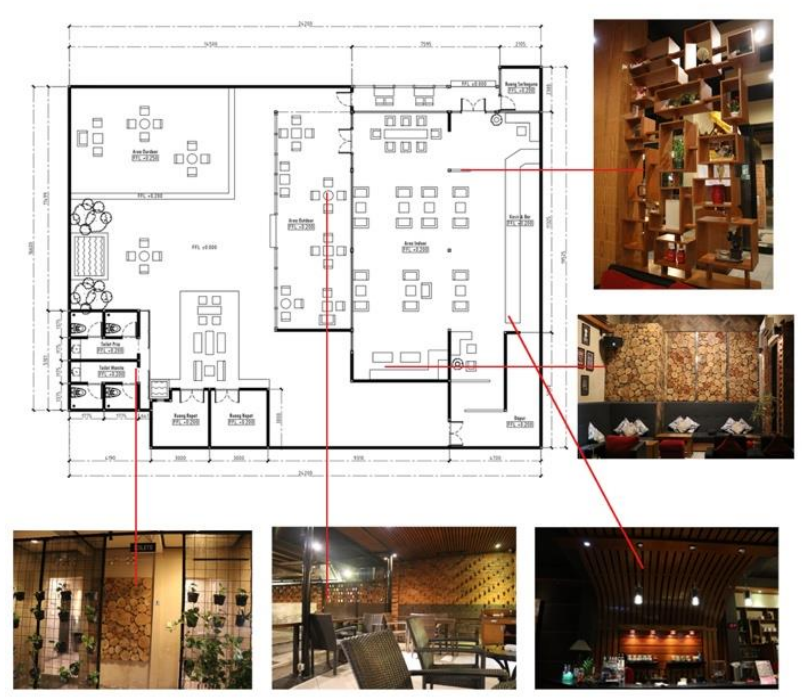

Gambar 5. Lingkungan dan kondisi dari Coffee Shop Coffee Secret's

\section{Alleyway Coffee}

Berdasarkan hasil wawancara Peneliti dengan pemilik, Turah Putra Prabawa, Alleyway berdiri pada tahun 2014 awal. Sejarah awal coffee shop ini adalah coffee shop yang berukuran kecil seperti gang atau jalan kecil dan jika dalam Bahasa Inggris disebut alleyway, terciptalah nama Alleyway itu sendiri. Alleyway pada awalnya hanya menjual kopi dan cake, kemudian pada tahun 2017 melakukan renovasi untuk memperbesar coffee shop ini. Segmentasi pasar mereka adalah menengah ke atas, anak-anak muda, pekerja yang senang bekerja di luar kantor. Sebelum pandemi, waktu operasional dimulai pagi hari dan pengunjungnya kebanyakan para orang tua murid yang mengantar anak sekolah di sekitar sana. Namun, setelah pandemi waktu operasionalnya dimulai pukul 11 untuk persiapan makan siang.

Interiornya didesain oleh tim mereka sendiri. Awalnya ingin menggunakan gaya vintage dengan sofa-sofa floral, tapi seiring berjalannya waktu, mereka merasa kesulitan untuk merawat sehingga konsepnya berganti dengan menerapkan gaya raw vintage dan menghemat biaya.

Berdasarkan hasil observasi, gaya raw vintage memang mendominasi desain interior dari 
Alleyway. Beberapa konsumen yang loyal dengan coffee shop ini memang menyukai suasananya yang nyaman, adanya area kebun/garden, sangat tenang, tidak berisik, Liajoni (25 tahun) dan Siska (31 tahun) sering mengunjungi Alleyway karena suasananya tenang sehingga nyaman untuk bekerja, dan menu yang ditawarkan juga memuaskan.

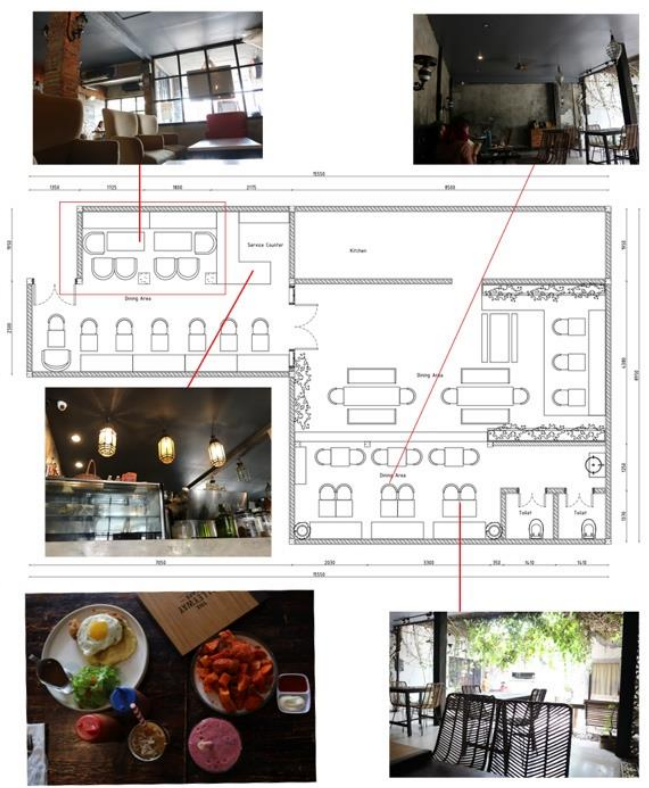

Gambar 6. Lingkungan dan kondisi dari Coffee Shop Alleyway Coffee

\section{Milestone Coffee}

Berdasarkan hasil wawancara Peneliti dengan pemilik yaitu Kenny Erawan, nama Milestone berasal dari makna milestone itu sendiri yang berarti batu loncatan. Filosofi tersebut yang menjadikan Milestone bukan coffee shop yang sekedar berjualan kopi, tapi juga sebagai tempat orang belajar sehingga bisa mencapai titik untuk fase hidupnya. Pemiliknya pun memang memberikan ilmu selain membuat kopi juga tentang pengembangan diri.

Segmentasi pasar Milestone adalah orang-orang lokal, anak-anak muda dan para pekerja. Belakangan ini banyak pekerja yang melakukan bekerja dari rumah (Work From Home) atau bekerja di luar kantor, sehingga untuk menyikapi hal tersebut Milestone menyiapkan banyak socket listrik. Sebelum pandemi, pengunjungnya tidak tentu tetapi justru setelah pandemi pengunjung datang di waktu tertentu seperti pukul 9.00-13.00.

Milestone tidak banyak melakukan iklan melalui media sosial. Biasanya hanya untuk promo-promo tertentu melalui Instagram dan menyediakan layanan pesan-antar melalui ojek daring. Konsep interior Milestone memiliki perubahan. Saat sebelum pandemi, Milestone menggunakan konsep industrial sedangkan, setelah pendemi interiornya berganti menjadi tropical yang sederhana dan bersih. Milestone juga sudah menerapkan protokol kesehatan pada interiornya, seperti letak tempat duduk yang berjarak sesuai aturan protokol kesehatan.

Berdasarkan hasil pengamatan dari sisi desain interiornya, sisa-sisa gaya industrialis masih terlihat dari elemen-elemen lampu dan furnitur, hanya saja bagian dinding telah dicat dengan warna yang terkesan tropical sehingga terasa lebih segar dan lebih cerah. Dengan perubahan interior ini pun, konsumen yang loyal pada coffee shop ini seperti Nita (25 tahun) dan Bayu (29 tahun) tetap menganggap desain interior dari Milestone kekinian, menarik dan instagrammable.

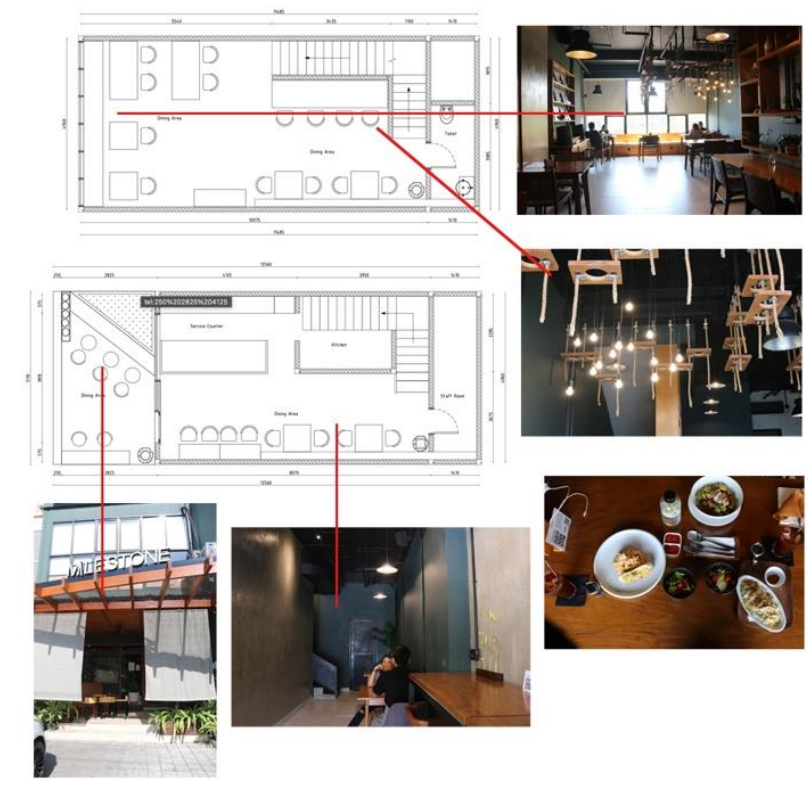

Gambar 7. Lingkungan dan kondisi dari Coffee Shop Milestone Coffee

\section{KESIMPULAN}

Berdasarkan hasil pengumpulan dan analisis data, terdapat tiga poin yang dapat didiskusikan yaitu tentang brand dalam paham kapitalisme konsumen, karakter ruang publik bagi generasi $\mathrm{Y}$ dan $\mathrm{Z}$ dalam konteks fungsi coffee shop, dan pemetaan korelasi antara elemen desain interior, brand sensuality, brand experience dan brand loyalty.

Dalam paham kapitalisme konsumen, sebuah brand tidak hanya berfungsi sebagai pelindung produk asli dari produk imitasinya, tetapi juga untuk menciptakan sebuah identitas dan gaya hidup baru yang disebut dengan economy of sign (U. Ermann, 2011). Prinsip economy of sign ini senada dengan individual lifestyle yang disampaikan oleh Hulten (2017), yakni konsumen dari generasi $\mathrm{X}, \mathrm{Y}$, dan $\mathrm{Z}$ menganggap bahwa 
proses konsumsi dari sebuah brand bertujuan untuk memuaskan ego dan self-fulfillment sehingga membawa nilai-nilai personal. Dengan demikian, brand secara tidak langsung akan membentuk identitas dan citra diri dari konsumennya.

Hal ini terlihat pada hasil penelitian ini yaitu Starbucks tetap menjadi brand yang paling banyak disukai oleh generasi Y dan Z di Denpasar. Nilai brand sensuality yang tinggi dari brand ini membuat experience yang dirasakan oleh konsumennya positif, sehingga mereka cenderung menghabiskan waktu yang lama di coffee shop ini. Selain itu, loyalitas konsumen terhadap brand ini juga cenderung tinggi, terlihat dari hasil penelitian dari konsumen dapat menghabiskan waktu lebih dari empat jam selama berada di coffee shop ini. Loyalitas yang tinggi ini selain disebabkan oleh brand experience yang positif, mungkin juga disebabkan oleh familiarity masyarakat terhadap brand ini, mengingat Starbucks sudah 17 tahun membuka gerainya di Bali. Aspek familiarity terkait dengan brand loyalti perlu menjadi pertimbangan penelitian ke depan. Dalam fenomena loyalitas konsumen generasi Z Denpasar terhadap brand Starbucks dapat dikaitkan dengan economy of sign atau individual lifestyle yaitu generasi $\mathrm{Z}$ walaupun dari sisi finansial sebagian besar belum mandiri, mereka berusaha untuk menjangkau proses konsumsi pada coffee shop Starbucks. Hal ini dilakukan sebagai upaya membentuk identitas diri mereka, sehingga harga yang ditawarkan oleh Starbucks yang tergolong tinggi untuk generasi $\mathrm{Z}$ saat ini, tidak menjadi kendala bagi mereka.

Perbedaan antara generasi $\mathrm{Y}$ dan $\mathrm{Z}$ terlihat pada variasi kegiatan yang mereka lakukan pada coffee shop. Variasi kegiatan kelompok generasi Z selain menikmati kopi, bekerja, dan bersosialisasi adalah berfoto dan mengunggah foto pada media sosial, variasi kegiatan ini tidak terlihat pada data responden generasi $\mathrm{Y}$ yang memiliki varian kegiatan untuk melakukan hobi, mencari inspirasi dan sekedar untuk bersantai di coffee shop. Variasi kegiatan ini ada kaitannya dengan kebutuhan generasi Y mencapai work-life balance atau keseimbangan antara pekerjaan dan kebutuhan pribadi, salah satunya adalah bersantai (Loughlin dan Barling, 2001, dalam Ng et al, 2010). Kebutuhan akan keseimbangan ini pula yang menyebabkan generasi Y cenderung menyukai gaya desain interior yang tidak mengekang seperti bersih, dekat dengan alam, bentuk sederhana, fleksibel dan fungsional (Susanti et al, 2018).
Berdasarkan hasil analisis data kuantitatif (data kuesioner) dan data kualitatif (data wawancara) dapat dirumuskan elemen-elemen desain interior coffee shop yang meningkatkan loyalitas konsumen adalah :

Tabel 9. Elemen lingkungan/interior coffee shop yang berpengaruh positif pada loyalitas

\begin{tabular}{ccc}
\hline No. & Kuantitatif & Kualitatif \\
\hline 1 & Musik/suara & Lingkungan sosial \\
\hline 2 & Temperatur & Kualitas kopi \\
\hline 3 & Material furniture & Aroma interior \\
\hline 4 & Kualitas kopi & Homy \\
\hline 5 & Menu & Privasi \\
\hline 6 & Aroma interior & Tidak berisik \\
\hline 7 & Warna interior & Area terbuka \\
\hline 8 & Bentuk furniture & Menu \\
\hline 9 & Pencahayaan interior & Instagrammable Interior \\
\hline 10 & Penyajian menu menarik &
\end{tabular}

Berdasarkan hasil pengumpulan data, dapat dikatakan bahwa seseorang mengingat sebuah tempat yang dianggap berkesan cenderung mengingat hal-hal yang bersifat tidak detail seperti menu makanan, rasa dan aroma kopi, aroma interior, gaya interior secara keseluruhan. Hal tersebut terlihat dari kata kunci yang diungkapkan konsumen saat diwawancara secara langsung. Sedangkan pada hasil kuesioner, pertanyaan mengarahkan responden untuk mengingat hal-hal yang bersifat mendetail, khususnya secara visual, seperti detail furnitur, detail tableware, kombinasi warna interior, dekorasi interior, pencahayaan interior.

Akan tetapi, apabila kata kunci yang diperoleh dalam wawancara diuraikan kembali, maka kata kunci tersebut sangat memiliki keterkaitan dengan desain interior dari coffee shop. Seperti contohnya tentang lingkungan sosial yang menyenangkan dari Jenar, memiliki keterkaitan dengan perasaan 'homy' yang dirasakan konsumen Coffee Secret's. Berdasarkan hasil penelitian dari Burris (2014, dalam Mahmoud, 2017) bahwa pengalaman kenyamanan di rumah (homy) terkait dengan interaksi sosialnya, kelebihan dari Jenar adalah keakraban antara barista dengan konsumen, interaksi sosial yang baik, menimbulkan perasaan nyaman pada konsumen sehingga lingkungan coffee shop terasa adaptif, dan konsumen memiliki kedekatan seperti berada di lingkungan rumah sendiri. Demikian pula juga dengan kata kunci tentang privasi, menurut Mahmoud (2017), privasi 
dalam konteks interior arsitektur terkait dengan ukuran, orientasi dan keterbukaan visual pandangan. Dengan demikian dapat dikatakan bahwa konfigurasi dan bentuk dari furnitur berperan untuk menentukan tingkat privasi dari sebuah area. Kualitas kopi sangat berkaitan dengan aroma interior dan hal tersebut telah dibuktikan pada pengolahan data kuesioner responden generasi Y dengan kualitas kopi yang dinilai baik berkorelasi dengan kesan aroma menyenangkan pada coffee shop dengan nilai korelasi tinggi sebesar 0,52. Kata kunci dari menu yang memuaskan, menarik, terkait dengan peralatan makan dan minum (tableware) sebesar 0,61, dan tableware juga memiliki korelasi yang tinggi untuk kesan dekorasi interior secara keseluruhan sebesar 0,61 .

Dengan demikian hasil penelitian ini disimpulkan bahwa elemen-elemen interior coffee shop yang memiliki pengaruh terhadap tingkat loyalitas konsumen adalah faktor fisik lingkungan seperti furnitur, pencahayaan, kombinasi warna, dekorasi interior, suara, temperatur sesuai dengan hasil penelitian Pecotic et.al. (2014), kualitas kopi yang baik, berpengaruh pada aroma yang menyenangkan pada coffee shop (Rodrigues, 2014), serta faktor non-fisik lingkungan seperti interaksi sosial yang dapat meningkatkan kenyamanan seperti di rumah sendiri pada coffee shop (Burris, 2014, dalam Mahmoud, 2017).

\section{DAFTAR PUSTAKA -}

Ermann, U. (2011). Consumer capitalism and brand fetishism: The case of fashion brands in Bulgaria. Brand. Brand. Geogr.pp. 107-124.

Hultén, B. (2017). Branding by the five senses : a sensory branding framework. J. Brand Strateg. Vol. 6. No. 3. pp. 281-292.

Mahmoud, HTH. (2017). Interior Architectural Elements that Affect Human Psychology and Behavior. The Academic Research Community publication, $1(1), 10$.

Ng, ESW. Schweitzer, L. Lyons, S. (2010). New Generation, Great Expectation : A Field Study of the Millenial Generation. Journal of Business and Psychology, Vol. 25.

Pecotic, M. Bazdan, V. Samardzija, J. (2014). Interior Design in Restaurants as a Factor Influencing Customer Satisfaction. Rochester Institute of Technology, 4. pp 10-14.
Riza, A F. Wijayanti, D M. (2018). The Triangle of Sensory Marketing Model: Does it Stimulate Brand Experience and Loyalty?. Esensi J. Bisnis dan Manaj. Vol. 8. No. 1, pp. 57-66.

Rodrigues, C. (2014). Brand sensuality and consumer-based brand equity. Diambil dari https://repositorioaberto.up.pt/bitstream/10216/76153/2/31376. pdf. 2014

Susanti, A. Mahadipta, NGD. Ariasandika, IMS . (2018). Karakteristik Interior Apartemen berkonsep S.O.H.O. bagi Tenaga Kerja Kreatif Generasi Milenial. SENADA. Vol. 1.

Susanti, A. Natalia, TW. (2018). Public space strategic planning based on $Z$ generation preferences. IOP Conf. Ser. Mater. Sci. Eng. Vol. 407. No. 1.

Töröcsik, M. Szűcs, K. Kehl, D. (2014). How generations think: Research on generation $Z$. Acta Univ. Sapientiae, Commun., vol. 1, pp. 23-45, 2014. 